\title{
CSR disclosure and corporate sustainability: evidence from the Shenzhen Stock Exchange
}

\author{
Kemi Yekini* \\ Nottingham University Business School, \\ University of Nottingham, \\ Jubilee Campus, UK \\ Email: kemi.yekini@nottingham.ac.uk \\ *Corresponding author
}

\author{
Han Li \\ Business School, \\ University of Leicester, UK \\ Email: 379492096@qq.com
}

\section{Paschal Ohalehi and Aruoriwo M. Chijoke-Mgbame}

Department of Accounting and Finance, De Montfort University, Leicester, UK

Email: paschal.ohalehi@dmu.ac.uk

Email: Marian.chijoke-mgbame@dmu.ac.uk

\begin{abstract}
In this paper we examined the relationship between CSR and corporate sustainability of Chinese companies listed on the Shenzhen Stock Exchange. This is necessitated by the high demand and increase in CSR activities and disclosures around the globe. Using a sample of 317 companies, we drew insights from the triple bottom line (TBL) and stakeholder theory to investigate the relationship between CSR and corporate sustainability. Data was analysed using structural equation modelling (SEM). A major contribution of this paper is the construction of a comprehensive CSR information disclosure index capable of guiding researchers and managers in measuring their CSR activities and reporting. The study's findings revealed that most Chinese companies stayed at the intermediate level of CSR information disclosure. Although CSR disclosure in economic and social dimension has a significant positive effect on corporate sustainability, our result shows a negative relationship with CSR in environmental dimension.
\end{abstract}

Keywords: corporate social responsibility disclosure; corporate sustainability; sustainability reporting; triple bottom line; TBL; stakeholder theory.

Reference to this paper should be made as follows: Yekini, K., Li, H., Ohalehi, P. and Chijoke-Mgbame, A.M. (2019) 'CSR disclosure and corporate sustainability: evidence from the Shenzhen Stock Exchange', Int. J. Business Governance and Ethics, Vol. 13, No. 3, pp.300-322. 
Biographical notes: Kemi Yekini is an Associate Professor in Accounting and the Accounting Division Research Director for PhD studies at the Nottingham University Business School. She is widely published in the fields of CSR and sustainability reporting, corporate governance and earnings management. She currently supervises doctoral students within these research areas.

Han Li obtained her MSc in Accounting and Finance from the University of Leicester Business School. Her research interest in CSR disclosure practices in China motivated her dissertation titled 'Corporate social responsibility information disclosure and corporate performance in China'. Her interest in taking her work forward culminated into the current research paper. She is currently an Audit Senior in professional practice.

Paschal Ohalehi is a Lecturer in the Accounting and Finance Department, De Montfort University, Leicester, UK. He is an active researcher with interests in CSR reporting, corporate governance, forensic accounting and fraudulent reporting in not-for-profit organisations. He has published his work in reputable journals and currently supervises $\mathrm{PhD}$ students in his research area.

Aruoriwo M. Chijoke-Mgbame received her $\mathrm{PhD}$ in Finance from Middlesex University, London, UK. She is a Lecturer in the Accounting and Finance Department, De Montfort University, Leicester, UK. She is a growing researcher with interests in corporate governance and corporate social responsibility and disclosures, corporate finance, and investment analysis. She has published in reputable academic journals.

\section{Introduction}

In this paper, we examine the effect of CSR disclosure (CSRD) on corporate sustainability (CS) amongst companies listed on the Shenzhen Stock Exchange. The rapid development of the Chinese economy over the last three decades brought with it social and environmental problems, which necessitated the strengthening of legislation by the Chinese government to encourage CSRD (Yekini et al., 2018). Therefore, faced with increasing regulatory and social pressure, Chinese companies, like their counterparts elsewhere in the Asia Pacific region, have embarked on CSRD to remain competitive in the global market. Hence, over the last two years, the Asia Pacific has witnessed a significant increase in CSR reporting (KPMG, 2013). As an important member of this region, China has a stronger motivation to encourage companies to disclose CSR information (Mullich, 2011). However, while government regulations set the guidelines for companies, the quality of CSRD still relies on individual companies, whose business decisions often centre on improving corporate performance (CP) (Yekini et al., 2015). It is expected, therefore, that decision makers will be interested in improving the quality of CSRD only if it will result in improved CP and sustainability. The focus of our study, therefore, is to explore the effect of CSRD on CS. It is hoped that the findings from this study will provide insights into the CSRD/CS relationship while also providing practical suggestions to Chinese companies on aspects of CSRD requiring more attention. Besides, previous studies on the subject have yet to reach a consensus on the CSRD/CS relationship (Beurden and Gössling, 2008). 
Our study employs the use of structural equation modelling (SEM) and analysis of moment structures (AMOS) in providing insights into CSRD and CS amongst the sampled firms. This is a departure from the wealth of literature (e.g., Gautam et al., 2017; Verbeeten et al., 2016; Yao et al., 2011; Adams et al., 1998; Ahmed and Courtis, 1999) within this space. Further, we drew insights from the triple bottom line (TBL) and stakeholder theory, while we also constructed a CSRD index. Overall, the study shows a general trend of a positive CSRD/CS relationship. However, while positive relationships are observed between CS and CSRD in the economic and social dimensions of CSR, an inverse relationship is observed between CS and CSRD in the environmental dimension.

In Section 2, we present the literature review on prior studies, while also highlighting the theoretical underpinnings and the hypotheses to be tested. Section 3 presents the methodology and the construction of the CSRD index as well as the methods adopted for analysing the data. Section 4 presents the empirical results while Section 5 concludes on the findings.

\section{Literature review, theory and hypotheses}

\subsection{Corporate sustainability and CSR}

There is a limited consensus in the extant literature on the relationship between CSR and CP (Margolis and Walsh, 2003). For example, Frost and Wilmshurst (2000) found that the most profitable companies have high levels of CSRD. Similarly, Ruf et al. (2001) found a positive relationship between CSR and sales growth. However, Beurden and Gössling (2008) reviewed studies on the relationship between CSRD and CP from 1991 to 2007 and found 23 studies in support of a positive CSRD/CP relationship, while the rest of the studies showed either inverse or insignificant relationships. Brammer and Millington (2005) suggested no real link between CP and CSRD. They found that companies with both unusually high and low CSR performance had better financial performance than other companies. On the other hand, a more recent study by Uadiale and Fagbemi (2012) on the Nigerian stock exchange showed a positive relationship between CSRD and profitability. Nevertheless, some scholars insist that there is a negative relationship between these two variables (Gras-Gil et al., 2016; Jawahar and McLaughlin, 2001). However, none of these studies have examined the relationships between CSR and CS.

In recent years, sustainability has been widely viewed as the goal of organisations. Studies such as Slaper and Hall (2011), Jackson et al. (2011), Loew et al. (2004) and Van Marrewijk (2003) have shown that there is overlap between CSR and sustainability. However, the best way to measure the level of an organisation's sustainability remains problematic. Elkington (1998) attempted a solution when he coined the phrase 'triple bottom line' (TBL). The TBL goes beyond the accountability for profits and shareholder value maximisation to include, accountability for nature and society. Consequently, Savitz (2013) asserts that poor TBL would result in negative effects on the survival and sustainability of a firm. Menz (2010) argue that firms' response to environmental and social issues under the pressure of government regulation may not result in CS, because social and environmental problems inhibit firms' sustainable developments (Jackson et al., 2011; Norman and MacDonald, 2004). For example, strikes caused by a conflict between employees and managers exert a negative influence on the normal operation of a 
firm. Resource shortages resulting from environmental degradation make it difficult for a firm to obtain raw materials. In addition, focusing on short-term financial objectives is not helpful for achieving long-term economic sustainability (Slaper and Hall, 2011). The TBL, therefore, provides a framework to evaluate the CS of organisations in a broader context (Slaper and Hall, 2011). In this paper, we employ the TBL framework as a measure of CS. We examine the relationship between CSR performance and the three dimensions of TBL performance: economic, environmental, and social. Since CSR activities can be identified based on the TBL, this helps us to design a CSRD index system (see Table 3). In addition, insights from the stakeholder theory (discussed below) help to clarify the stakeholder groups benefiting from the CSR activities and thus helps in refining the index. This is discussed further in Section 3.2.

\subsection{Stakeholder theory and CSR}

Stakeholder theory provides a unique insight into the requirements for an enabling sustainable business environment. It suggests that the operating environment is shaped by the demands of stakeholders. The proponents of stakeholder theory, Freeman (1984), Mitchell et al. (1997) and Clarkson (1995), argue that to achieve sustainability, managers should take into consideration those stakeholders, either external or internal to the firm, who can affect or are affected by the firms' operations. Mitchell et al. (1997), however, pointed out that managers often pay uneven attention to different stakeholders, since some stakeholders do not have legal or regulatory relationships with the company. In general, however, stakeholder theory breaks through the traditional shareholder primacy theory to further refine the TBL into specific stakeholder groups. It clarifies the responsibility range within which a firm should conduct CSR management (Bhattacharyya, 2010). In addition, stakeholder theory lays a foundation for the study of CSRD. Yekini et al. (2017) argue that CSRD based on stakeholders' perspectives can improve communication between companies and stakeholders. It helps to achieve real and effective information disclosure (Yekini and Jallow, 2012; Yekini, 2012). For stakeholders, they can perceive their important roles in a company's strategy and management (Yekini et al., 2015).

\subsection{Research hypotheses}

To achieve the aim of this paper, which is to examine the CSRD/CS nexus, we followed insights from the TBL principles and divided CSRD into economic, environmental, and social dimensions as discussed below.

\subsubsection{CSRD in the economic dimension}

Neumayer (2000, p.2) asserts that "economic growth is for the good of most stakeholders in society" because this means more profit, more jobs, higher wages for the workforce and higher tax revenue for the government. We argue that economic performance forms the basis and guarantees environmental and social responsibility since CS is the key objective of an organisation in the long run. This is because sustainable social and environmental performance requires adequate economic resources. Failure in the economic dimension will have a negative influence on CSR activities in the environmental and social dimensions. Consequently, we argue that the economic 
dimension is the starting point of sustainable CSR activities. From the literature review, the economic dimension can be divided into financial performance and market performance. The following discussion focuses on the relationship between CSRD and these two aspects.

Following insights from stakeholder theory, we argue that CSRD in financial performance should include information on shareholders, creditors, suppliers and customers, because, these stakeholder groups can affect the operating results of a company (Yekini et al., 2015; Laiho, 2011). For example, Laiho (2011) argued that a conflict of interests between shareholders and creditors could adversely affect financial performance. Therefore, for CS, it is important that firms safeguard the interests of these two sets of stakeholders. CSRD serves as an effective communication tool in which actions taken by the firm to safeguard such stakeholder interest is well defined. This is expected to increase their confidence in the firm and in turn, results in increased investments and consequently financial performance. Similarly, Li et al. (2006) assert that good supply chain management can bring competitive advantage to a firm. As specific actions to improve supplier management are identified in CSRD, it encourages suppliers to strengthen collaboration with the firm (Wagner and Johnson, 2004). They are likely to allow firms to purchase on credit. They are also encouraged to get involved in companies craft process re-engineering, which makes the supplied products more suitable for companies. These may result in increased working capital, turnover and reduction in production cost, hence improving financial performance. Improved financial performance may also result in improved product and service quality. Chi and Gursoy (2009) found that there is a positive relationship between financial performance and customer satisfaction. Pivato et al. (2008) pointed out that good CSR performance attracts consumer trust and that in turn can affect consumers' subsequent actions such as purchasing more products from the firm. Their research further suggested that CSR activities can improve financial performance. Since CSRD reflects CSR activities, high-level CSRD indirectly improves financial performance. Customers get to know the actions taken by companies to protect their own benefits through CSRD. Hence, they are happy to continue with their patronage of firms' products and services.

CSRD on market performance includes information on shareholder value. Hillman et al. (2001) assert that shareholder value has a direct relationship with the market return. Similarly, Bird et al. (2007) find that market performance is influenced by CSR activities. The fulfilment of responsibilities to shareholders can lead them to have confidence in the capital returns so that a firm can attract more investors, thus improving market performance. In addition, although creditors, suppliers and customers cannot directly affect market return, they have a great influence on business operations. Taking responsibility for these stakeholders through CSR activities helps achieve CS (Van Marrewijk, 2003). It is also consistent with the interests of investors because they value the future cash flow. CSR activities targeting these three stakeholders also help attract more investment and improve market performance. In general, CSRD in the economic dimension can positively influence market performance.

Based on the discussion above, market performance and financial performance can be enhanced through CSRD in the economic dimension. Thus, CS can be improved by disclosing CSR information about stakeholders who have economic relationships with the company. We, therefore, put forward the following hypotheses: 
H1a There is a positive relationship between the economic dimension of CSRD and environmental dimension.

$\mathrm{H} 1 \mathrm{~b}$ There is a positive relationship between the economic dimension of CSRD and social dimension.

H1c There is a positive relationship between the economic dimension of CSRD and market performance.

H1d There is a positive relationship between the economic dimension of CSRD and financial performance.

\subsubsection{CSRD in the environmental dimension}

There has been a heated discussion over the years on the relationship between CSR in the environmental dimension and CS. Aggarwal (2013) notes that failure in environmental responsibility will likely have a negative effect on a firm's reputation which may increase regulation costs. This will, in turn, reduce the firm's competitiveness and affect its stock market value. Cormier and Magnan (2007) argue that investors view environmentally responsible companies as attractive and less risky investments with good prospects. Nakao et al. (2007a) found that firms with good environmental performance have higher Tobin's Q, hence, good CSR management in the environmental dimension has positive effects on a firm's market performance. Other scholars suggest that good environmental performance has a positive influence on financial performance (Freedman and Patten, 2004; Griffin and Sun, 2013). For example, Murphy (2002) and Nakao et al. (2007b) investigated the relationship between CSR in the environmental dimension and financial performance and found a positive relationship between the two variables. King et al. (2002) argue that when firms engage in and disclose environmental protection activities, they send positive signals that create a good corporate image, improves product sales, and in turn improves the financial performance of the firm. Thus, suggesting that environmental dimension of CSRD enhances market and financial performance. Hence, this study puts forward the following hypotheses:

$\mathrm{H} 2 \mathrm{a}$ There is a positive relationship between the environmental dimension of CSRD and market performance.

$\mathrm{H} 2 \mathrm{~b}$ There is a positive relationship between the environmental dimension of CSRD and financial performance.

\subsubsection{CSRD in the social dimension}

In the CSRD index in Table 3, CSR information on the social dimension includes government, employee management, and social welfare as these are the sources of social pressures on corporations. Baron (2010) notes that constant social pressure will have a negative effect on CS and that a firm which is able to deal with social pressure will have long-lasting CS. Achieving CS involves compliance with capital market rules and other government regulations since non-compliance may result in being delisted from the capital market. Hence, compliance with market regulations forms the basis for achieving market performance. In addition, Holmes (2010) found that government policies can affect corporate market performance. He argues that policies are precursors to changes in 
the marketplace and investors need to track and monitor those policies. Those firms actively following government policy may have more competitiveness in the market. Moreover, socially responsible investments have been a growing trend in recent years. More and more investors favour companies taking responsibility for society (Yekini et al., 2017). Hence, these kinds of companies have more attractiveness in the capital market, leading to the improvement of market performance. Similarly, from the aspect of financial performance, CSR activities in the social dimension have a positive influence on the operating results of a firm. In addition, Pivato et al. (2008) suggest that CSR activities targeting employees can enhance their loyalty and satisfaction, which helps improve their working efficiency. Moreover, Mandhachitara and Poolthong (2011) find that CSR activities such as conducting social welfare programmes can improve a firm's social reputation and customer loyalty. In this way, a firm not only reduces the cost of dealing with social pressure but also obtains a stable market share. These benefits promote the competitiveness of a firm which ultimately results in improved financial performance. From the above discussion, CS can be achieved through CSR management of social actors. Market performance and financial performance can be enhanced through CSRD in the social dimension. We therefore propose the following hypotheses:

H3a There is a positive relationship between the social dimension of CSRD and market performance.

$\mathrm{H} 3 \mathrm{~b}$ There is a positive relationship between the social dimension of CSRD and financial performance.

Table 1 Summary of proposed hypotheses

\begin{tabular}{|c|c|c|}
\hline & Hypotheses & Expected relationship \\
\hline H1a & The economic dimension of CSRD and environmental dimension & Positive \\
\hline $\mathrm{H} 1 \mathrm{~b}$ & The economic dimension of CSRD and social dimension & Positive \\
\hline $\mathrm{H} 1 \mathrm{c}$ & The economic dimension of CSRD and market performance & Positive \\
\hline H1d & The economic dimension of CSRD and financial performance & Positive \\
\hline $\mathrm{H} 2 \mathrm{a}$ & The environmental dimension and market performance & Positive \\
\hline $\mathrm{H} 2 \mathrm{~b}$ & The environmental dimension and financial performance & Positive \\
\hline $\mathrm{H} 3 \mathrm{a}$ & The social dimension and market performance & Positive \\
\hline $\mathrm{H} 3 \mathrm{~b}$ & The social dimension and financial performance & Positive \\
\hline
\end{tabular}

Figure 1 Summary of proposed hypotheses

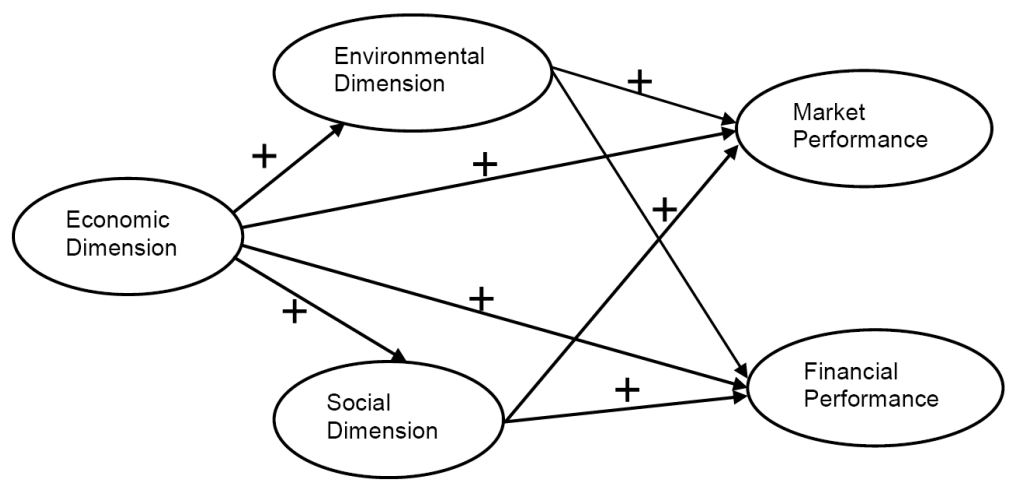


Table 1 summarises the hypotheses to be tested while also indicating the expected relationship between CSRD and each dimension of CS, while the model in Figure 1 further illustrates these relationships.

\section{Methods}

\subsection{Sample and data}

We examined all Chinese companies listed on the main board market of the Shenzhen Stock Exchange up until 31 December 2013. Data were obtained from published reports. To improve comparability and rationality, some listed companies were eliminated. Firstly, financial firms as they have special industry disclosure standards in China. In addition, their total assets hold a large percentage of the whole market, which may have an influence on the research results. Secondly, since 1998 Shenzhen Stock Exchange has conducted 'special treatment' (ST) on listed companies that have abnormal financial positions to inform investors of the investment risk (Qiang, 2003). The stocks of these companies are called ST stocks. Since the abnormal value may have adverse effects on statistical results, these ST stocks were deleted from the sample. Thirdly, we eliminated accounting firms and companies with qualified audit opinions to improve the reliability of research results. Based on the above criteria, the final sample consisted of 317 listed companies.

The data on CS were extracted from the 'Wind Info' database. This database was established by Wind Information Co. Ltd (Wind Info), a leading integrated service provider of financial data, information, and software. Wind Info serves more than $90 \%$ of the firms in the Chinese market (Wind Info, 2015). The CSR information were hand collected from audited published annual reports of the 317 listed companies. Specifically, the reports were collected from the official information disclosure website approved by the China Securities Regulatory Commission (CSRC). The CSR information was obtained using keyword search based on the indicators in the established CSRD index system. If a term was not discovered by the search engine, we examined the whole report in order to guarantee the comprehensiveness and accuracy of the data. The process is described further in the next sub-section.

\subsection{Measurement of CSRD}

Consistent with previous studies on CSRD (Richardson and Welker, 2001; Haniffa and Cooke, 2002; Gjølberg, 2009; Yekini et al., 2015), we adopt the index method of measurement as this is considered as a relatively accurate measurement approach for CSRD (Turker, 2009). This approach breaks CSR information into several levels. The higher level contains several subcategories, which form the segmenting indexes. These segmenting indexes are scored based on the actual situation of disclosed CSR information. The scores are then gathered to obtain the total score of a firms' CSRD. This approach, aside from being practical, also overcomes the problem of ambiguous categories in content analysis. Similar indices include the MSCI KLD 400 Social Index and the Dow Jones sustainability indexes (DJSI) (RobecoSAM, 2015).

In this study, we followed the principles of TBL as adopted by the famous KLD and DSJI in the construction of our CSRD index for Chinese companies listed on the 
Shenzhen stock exchange. The CSR information was divided into economic, environmental, and social dimensions. However, because the first-class indicators cannot be observed directly, they are reflected by the incorporated second-class indicators. We obtained the second-class indicator scores by summing up the scores for the third-class indicators. We categorised the information on the third-class indicators into 'disclosed' or 'non-disclosed'. A score of 1 is given where a piece of information is disclosed and 0 otherwise. Therefore, the total CSRD score ranges from 0 to 30 . This follows the idea of equal weighting as argued by the TBL. The argument is that the economy, society, and environment are interrelated and that the three elements are the pillars of CS (Savitz, 2013). Furthermore, Jackson et al. (2011) argue that focus on one dimension only will adversely affect CS. For example, if a heavily polluting company focuses only on the economic dimension, workplace safety and the natural environment are likely to be ignored. The consequence could be a breakout of occupational disease and deterioration of living standards in the environment where the firm operates. This could, in turn, increase hospitalisation costs, which may be shifted to the society and government. Moreover, the firm may be punished by regulators, which may negatively affect its economic performance.

\subsection{Measurement of corporate performance}

There is a plethora of studies on CP measurement and yet no consensus on the best measure of CP (Tsoutsoura, 2004). However, based on the data source of the previous studies, the measurement of $\mathrm{CP}$ can be subsumed into two categories: market performance and financial performance (Schneider et al., 2003). Market performance refers to the capital market data reflecting the return to shareholders. Financial performance refers mainly to financial statement data, which reflect the operating results of a company. Regularly used market performance measurements include Tobin's Q, price to book ratio $(\mathrm{P} / \mathrm{B})$ and price to cash flow ratio $(\mathrm{PCF})$. Financial performance indicators regularly used in the literature include return on assets (ROA) and return on equity (ROE). Most previous studies have focused on either of the two to measure CP. However, to provide a full picture of a firm's operating results, this study employs Tobin's Q, P/B ratio and PCF as indicators to measure market performance. ROA, ROE and operating profit growth rate (OPGR) were selected as the financial performance indicators.

\section{Data analysis and results}

\subsection{Descriptive statistics of CSRD}

Prior studies have used either 'high level or 'low level' to describe their results on CSRD (Jamil et al., 2003; Stanny and Ely, 2008). In order to more intuitively reflect the level of CSRD in China, we divided the listed companies into three categories: advanced, intermediate, and elementary levels, based on their CSRD situation (see Table 2). Companies in the advanced category have a strong sense of CSR and awareness of information disclosure. They have established a comprehensive CSR management system. Their CSRD is relatively full, fair and they are seen as activists of CSRD in China. On the other hand, the intermediate companies have a certain level of CSR 
awareness. Although their CSRD is not comprehensive, they are expanding the range within which they are able to conduct CSR management. Companies in this group have much room to improve their CSRD and can be regarded as pursuers of CSRD in China. Lastly, the elementary companies have weak consciousness of CSR. They lack CSRD and if there is any form of disclosure, it is partial and scattered. This category of companies can be viewed as beginners of CSRD in China.

From Table 2, we observe that the largest group consist of companies with intermediate level of CSRD. They make up $64 \%$ of the sample with 204 companies. Next is the elementary level making up $26 \%$ of the sample with 81 companies. The advanced group occupy $10 \%$ of the total sample, with 32 companies scoring at least 20 .

Table 2 CSRD Categories

\begin{tabular}{|c|c|c|c|c|}
\hline Categories & Score range $(0-30)$ & Number of companies & \multicolumn{2}{|c|}{ Proportion } \\
\hline \multirow{3}{*}{$\begin{array}{l}\text { Advanced level } \\
\text { Intermediate level } \\
\text { Elementary level }\end{array}$} & At least 20 & 32 & \multicolumn{2}{|c|}{$10 \%$} \\
\hline & Between 10 and $1 \mathrm{~s}$ & 204 & \multicolumn{2}{|c|}{$64 \%$} \\
\hline & 9 or below & 81 & \multicolumn{2}{|c|}{$26 \%$} \\
\hline \multicolumn{5}{|c|}{ Table 3 CSRD index } \\
\hline $\begin{array}{l}\text { 1st class } \\
\text { indicators }\end{array}$ & $\begin{array}{l}\text { 2nd class } \\
\text { indicators }\end{array}$ & $3 r d$ class indicators & Samples & Proportion \\
\hline \multirow{12}{*}{$\begin{array}{l}\text { Economic } \\
\text { dimension }\end{array}$} & \multirow{3}{*}{$\begin{array}{l}\text { Responsibility for } \\
\text { shareholders } \\
\text { (SHR) }\end{array}$} & Dividend payment & 283 & $89.27 \%$ \\
\hline & & Corporate growth & 271 & $85.49 \%$ \\
\hline & & Corporate risk control & 269 & $84.86 \%$ \\
\hline & \multirow{2}{*}{$\begin{array}{l}\text { Responsibility for } \\
\text { creditors (CRR) }\end{array}$} & Repayment on schedule & 281 & $88.64 \%$ \\
\hline & & Use money by contract & 58 & $18.30 \%$ \\
\hline & \multirow{3}{*}{$\begin{array}{l}\text { Responsibility for } \\
\text { suppliers (SUS) }\end{array}$} & Stable cooperative relationship & 101 & $31.86 \%$ \\
\hline & & Financial support & 47 & $14.83 \%$ \\
\hline & & Against unfair competition & 51 & $16.09 \%$ \\
\hline & \multirow{4}{*}{$\begin{array}{l}\text { Responsibility for } \\
\text { customers (CUR) }\end{array}$} & Product safety and quality & 176 & $55.52 \%$ \\
\hline & & After-sale service & 104 & $32.81 \%$ \\
\hline & & Customer satisfaction & 56 & $17.67 \%$ \\
\hline & & Suitable credit policy & 41 & $12.93 \%$ \\
\hline \multirow{8}{*}{$\begin{array}{l}\text { Environmental } \\
\text { dimension }\end{array}$} & \multirow{3}{*}{$\begin{array}{l}\text { Energy saving } \\
\quad \text { (ENS) }\end{array}$} & Use renewable resources & 20 & $6.31 \%$ \\
\hline & & Recycling economy policy & 53 & $16.72 \%$ \\
\hline & & Green office & 103 & $32.49 \%$ \\
\hline & \multirow[t]{2}{*}{$\begin{array}{l}\text { Pollution control } \\
\text { (POC) }\end{array}$} & $\begin{array}{l}\text { Pollution and emission } \\
\text { reduction }\end{array}$ & 87 & $27.44 \%$ \\
\hline & & $\begin{array}{l}\text { Use equipment for pollution } \\
\text { control }\end{array}$ & 49 & $15.46 \%$ \\
\hline & \multirow{3}{*}{$\begin{array}{l}\text { Environmental } \\
\text { management } \\
(\text { ENM) }\end{array}$} & $\begin{array}{c}\text { Environmental protection } \\
\text { training }\end{array}$ & 71 & $22.40 \%$ \\
\hline & & $\begin{array}{l}\text { Environmental protection } \\
\text { programmes }\end{array}$ & 75 & $23.66 \%$ \\
\hline & & $\begin{array}{l}\text { Develop green products and } \\
\text { technology }\end{array}$ & 107 & $33.75 \%$ \\
\hline
\end{tabular}


Table 3 CSRD index (continued)

\begin{tabular}{|c|c|c|c|c|}
\hline $\begin{array}{l}\text { 1st class } \\
\text { indicators }\end{array}$ & $\begin{array}{l}\text { 2nd class } \\
\text { indicators }\end{array}$ & 3rd class indicators & Samples & Proportion \\
\hline \multirow{10}{*}{$\begin{array}{l}\text { Social } \\
\text { dimension }\end{array}$} & \multirow{3}{*}{$\begin{array}{l}\text { Responsibility for } \\
\text { government } \\
\text { (GOV) }\end{array}$} & Comply with regulations & 317 & $100.00 \%$ \\
\hline & & $\begin{array}{l}\text { Cooperate with government to } \\
\text { do social good }\end{array}$ & 26 & $8.20 \%$ \\
\hline & & Tax payment by law & 317 & $100.00 \%$ \\
\hline & \multirow{4}{*}{$\begin{array}{l}\text { Employee } \\
\text { management } \\
(\text { EMM })\end{array}$} & $\begin{array}{l}\text { Workplace safety and welfare } \\
\text { guarantee }\end{array}$ & 306 & $96.53 \%$ \\
\hline & & Employee training & 211 & $66.56 \%$ \\
\hline & & $\begin{array}{c}\text { Equity of employment and } \\
\text { promotion }\end{array}$ & 53 & $16.72 \%$ \\
\hline & & Fair performance appraisal & 134 & $42.27 \%$ \\
\hline & \multirow{3}{*}{$\begin{array}{l}\text { Social welfare } \\
\quad(\text { SOW })\end{array}$} & Charitable donations & 223 & $70.35 \%$ \\
\hline & & Provide employment security & 69 & $21.77 \%$ \\
\hline & & Social welfare programmes & 57 & $17.98 \%$ \\
\hline
\end{tabular}

Table 3 shows the detailed statistics of CSRD. We observe from the table that most of the sampled companies pay attention to the stakeholder dimension. We find that $89 \%$ disclose dividend payment while $85 \%$ report on corporate growth and corporate risk control. With respect to creditors, $89 \%$ of Chinese companies focus on repayment on schedule. What is particularly striking is that $100 \%$ of the sampled companies disclosed information about complying with regulations and tax payment by law. This could be because of the dire consequences for flouting the laws and not paying taxes in China. Similarly, 97\% (306 firms) disclose information about workplace safety and welfare guarantees. We find that Chinese companies have worse performance in the environmental dimension. The proportion of each third-class indicator in this dimension is below 35\%. This finding is consistent with the research done by Meng et al. (2013) as they also found that the level of environmental information disclosure is low in China. This means that Chinese companies need to strengthen their environmental management practices. Within the social dimension, in the aspect of social welfare, about $70 \%$ of firms report charitable donations, and there are a small number of companies disclosing information about social welfare programmes and providing employment security.

From Table 4, the social and economic dimensions have the highest average disclosure scores, with 5.41 and 5.16, respectively. The environmental dimension disclosure score is only 1.73, which is the lowest average score among the three dimensions. There is, therefore, a big gap between environmental disclosure and the other two disclosure dimensions. This shows that Chinese listed companies have good performance in taking responsibility in terms of economic and social dimensions. In contrast, their performance in terms of the environmental dimension of CSR is poor. The reason for the high score in the economic dimension is easy to ascertain; CSR in the economic dimension is seen as the most fundamental responsibility of a firm. Without corporate growth, a firm finds it hard to survive in the fiercely competitive market. Also, shareholders see dividend payment as a sign of growth. The good performance in the social dimension may be associated with Chinese Government reforms. Kanbur and Zhang (2005) find that in recent years, China has conducted a series of urban and rural 
reforms to improve social welfare and protect employee interests. Corporations are therefore required to follow government policies to take responsibility for society. The low disclosure score in the environmental dimension is also not surprising. This can be attributed to the lack of proper environmental regulations and enforcement agents (Liu and Anbumozhi, 2009; Yekini et al., 2018). Many Chinese companies lack awareness of environmental responsibility, which leads to inadequate information disclosure in the environmental dimension. Babiak and Trendafilova (2011), however, note that there is increasing concern among the public about environmental protection, but that firms may not be able to meet such demands in the short-term, hence the poor performance in the environmental dimension.

Table 4 Dimension scores of CSRD

\begin{tabular}{lccccc}
\hline Dimension & Score range & Minimum & Maximum & Average & Standard deviation \\
\hline Economic & $0-12$ & 1 & 10 & 5.16 & 1.46 \\
Environmental & $0-8$ & 0 & 8 & 1.73 & 1.78 \\
Social & $0-10$ & 2 & 9 & 5.41 & 1.50 \\
\hline
\end{tabular}

\subsection{Individual dimension disclosure analysis}

\subsubsection{Economic disclosure}

From Table 5, Chinese listed companies have very good disclosure performance in terms of taking responsibility for shareholders. Disclosures to shareholders have an average score of 2.5, which is far higher than the scores of the other second-class indicators. The indicators of taking responsibility for creditors and customers show similar average scores: both are more than 1 and less than 2. However, performance in taking responsibility for suppliers $(0.96)$ is poor when compared to the other indicators.

From Table 5 disclosure scores for shareholders, creditors, and customers contribute to the high score of CSRD in the economic dimension. Sawayda (2013) pointed out that as the owners of the firm, shareholders are the most powerful stakeholder. Therefore, the responsibility to shareholders is the fundamental corporate responsibility in the economic dimension. Firms recognise the importance of safeguarding shareholders' interests and conduct good management of shareholders; hence resulting in good CSRD about shareholders. Similarly, responsibility to creditors is of paramount importance. Failure to fulfil this responsibility may result in capital chain rupture (Zhang and $\mathrm{Gu}, 2012$ ). Since creditors have a stake in the business operation, a firm needs to treat them with caution. This produces the relatively good CSRD about creditors. As for responsibility for customers, a firm has to deal with it positively because product quality supervision has become increasingly strict in China (De-zhong et al., 2006). In addition, with the rise of customer power, firms face more and more pressure on product safety and quality (Peppard, 2000). If a firm does not care about customers' demands, then CS will be at risk. CSRD is one of the ways to improve customer satisfaction and obtain their trust. The low disclosure score (0.96) for suppliers may be associated with the disclosure standards in annual reports. CSRC does not particularly require Chinese listed companies to disclose detailed information about their suppliers. Firms only need to disclose the top five suppliers and related transactions. Since Chinese firms lack awareness of the 
importance of suppliers, they do not voluntarily disclose the CSR information on suppliers.

Table 5 Economic dimension scores of CSRD

\begin{tabular}{lccccc}
\hline $\begin{array}{l}\text { 2nd class } \\
\text { indicators }\end{array}$ & Score range & Minimum & Maximum & Average & Standard deviation \\
\hline SHR & $0-3$ & 1 & 3 & 2.5 & 0.74 \\
CRR & $0-2$ & 0 & 2 & 1.17 & 0.50 \\
SUS & $0-3$ & 0 & 3 & 0.96 & 0.68 \\
CUR & $0-4$ & 0 & 3 & 1.24 & 0.92 \\
\hline
\end{tabular}

\subsubsection{Environmental dimension analysis}

From Table 6, each indicator of environmental disclosure dimensions has an average score of less than 1. Among these three indicators, environmental management has the highest performance with a score of 0.69 . Energy saving is next with a score of 0.53 , while pollution control has a very poor score of 0.37 . The plausible reason for this poor environmental disclosure is that the Chinese market is still at its developing stage and the constraining forces to limit environmentally destructive activities are weak (Yekini et al., 2018). Again, the environment, as Mitchell et al. (1997) postulate, is a dependent stakeholder with the attributes of legitimacy and urgency but who have no power to put forward their claims. They depend on the dominant stakeholders (government regulator and public supervisors) who are passive and have limited effects on environmental matters in China [Yekini, (2012), pp.40-44]. The ultimate solution, therefore, depends on the government setting up minimum regulatory requirements for the disclosure of environmental information by firms as well as corporations taking the initiative to reduce environmental pollution.

Table 6 Environmental dimension score of CSRD

\begin{tabular}{lccccc}
\hline $\begin{array}{l}\text { 2nd class } \\
\text { indicators }\end{array}$ & Score range & Minimum & Maximum & Average & Standard deviation \\
\hline ENS & $0-3$ & 0 & 3 & 0.53 & 0.73 \\
POC & $0-2$ & 0 & 2 & 0.37 & 0.66 \\
ENM & $0-3$ & 0 & 3 & 0.69 & 0.85 \\
\hline
\end{tabular}

\subsubsection{Social dimension analysis}

From Table 7, Chinese companies show good performance in taking responsibility for government and employee management. But the social welfare indicators obtain a low score of only 1.38 . The research results show that most listed companies comply with regulations and policies. They pay taxes by law and cooperate with local government to obtain policy support and a relaxed business environment. The high score for employee management (2.06) is consistent with the new reforms by the Chinese Government to promote employees' interest. Also, with the promotion of labour law in recent years, firms began to strengthen employee management and take responsibility for employee welfare (Cooke, 2005). 
In the aspect of social welfare, the sampled companies have good performance on charitable donations. From Table 3, we find that 223 companies, about $70 \%$ of the sample, disclose information on charitable donations. Brammer and Millington (2005) suggest that charitable donation is a direct and effective way of building a good corporate image, which has a positive influence on CS. However, the scores on providing employment security and social welfare programmes are low, which means that these responsibilities are not of concern to Chinese companies. This may be due to lack of awareness of community and public welfare. Consistent with Johnson et al. (2008), corporations are found to pay little attention to their responsibility for community stakeholders.

Table 7 Social dimension score of CSRD

\begin{tabular}{lccccc}
\hline $\begin{array}{l}\text { 2nd class } \\
\text { indicators }\end{array}$ & Score range & Minimum & Maximum & Average & Standard deviation \\
\hline GOV & $0-3$ & 2 & 3 & 2.11 & 0.24 \\
EMM & $0-4$ & 1 & 4 & 2.06 & 0.91 \\
SOW & $0-3$ & 0 & 3 & 1.38 & 0.63 \\
\hline
\end{tabular}

\subsection{Hypothesis testing using structural equation model}

This section explores the effects of CSRD on CS based on the above results. To avoid any bias and inconsistent results, we re-examined the data for extreme values. This resulted in a reduced sample of 287 companies.

Table 8 Descriptive statistics and normal distribution analysis

\begin{tabular}{lccccccc}
\hline Indicator & Sample & Average & STDEV & Skewness & Std. error & Kurtosis & Std. error \\
\hline SHR & 287 & 2.41 & 0.75 & -1.38 & 0.14 & 2.01 & 0.29 \\
CRR & 287 & 1.01 & 0.50 & 0.03 & 0.14 & 1.14 & 0.29 \\
SUS & 287 & 0.56 & 0.67 & 1.00 & 0.14 & 0.69 & 0.29 \\
CUR & 287 & 1.04 & 0.91 & 0.51 & 0.14 & -0.58 & 0.29 \\
ENS & 287 & 0.52 & 0.71 & 1.07 & 0.14 & 0.01 & 0.29 \\
POC & 287 & 0.37 & 0.66 & 1.53 & 0.14 & 0.98 & 0.29 \\
ENM & 287 & 0.67 & 0.84 & 1.01 & 0.14 & 0.06 & 0.29 \\
GOV & 287 & 2.07 & 0.26 & 1.30 & 0.14 & 2.92 & 0.29 \\
EMM & 287 & 2.05 & 0.97 & 0.51 & 0.14 & -0.78 & 0.29 \\
SOW & 287 & 0.99 & 0.80 & 0.51 & 0.14 & -0.15 & 0.29 \\
TQ & 287 & 0.26 & 0.19 & 1.44 & 0.14 & 2.19 & 0.29 \\
PB & 287 & 0.34 & 0.17 & 1.20 & 0.14 & 1.58 & 0.29 \\
PCF & 287 & 0.56 & 0.12 & -0.19 & 0.14 & 2.13 & 0.29 \\
ROA & 287 & 0.31 & 0.31 & 0.12 & 0.14 & 0.41 & 0.29 \\
ROE & 287 & 0.42 & 0.14 & 0.85 & 0.14 & 2.89 & 0.29 \\
OPGR & 287 & 0.59 & 0.10 & -0.41 & 0.14 & 0.62 & 0.29 \\
\hline
\end{tabular}


To examine the effect of CSRD on CS, we used the SEM. SEM is a more complex multivariate estimation technique that involves several conventional multivariate procedures such as regression analysis, factor analysis, correlation, ANOVA and more, which are built into one model. SEM begins with the development of theories derived from existing literature and empirical results. It involves five basic steps: model specification, model identification, model estimation, a test of the model fit, and if need be, model manipulation (Bollen, 1989). To effectively conduct SEM analysis, the data has to be normally distributed. One confirmation of normality is that the absolute value of skewness should be less than 2 and the absolute value of kurtosis less than 5 (Kline, 1998). To carry out the SEM, we used the AMOS software. From Table 8, we find that the sample data conform with this requirement.

Based on the proposed hypotheses, we estimate the following SEM. From Figure 2, we find that there are five latent variables, namely the economic dimension, the environmental dimension, the social dimension, market performance, and financial performance. Each of these latent variables is measured by three observed variables, except the economic dimension with four observed variables. Figure 2 also shows that the model is recursive without bidirectional causality.

Figure 2 Structural equation model (see online version for colours)

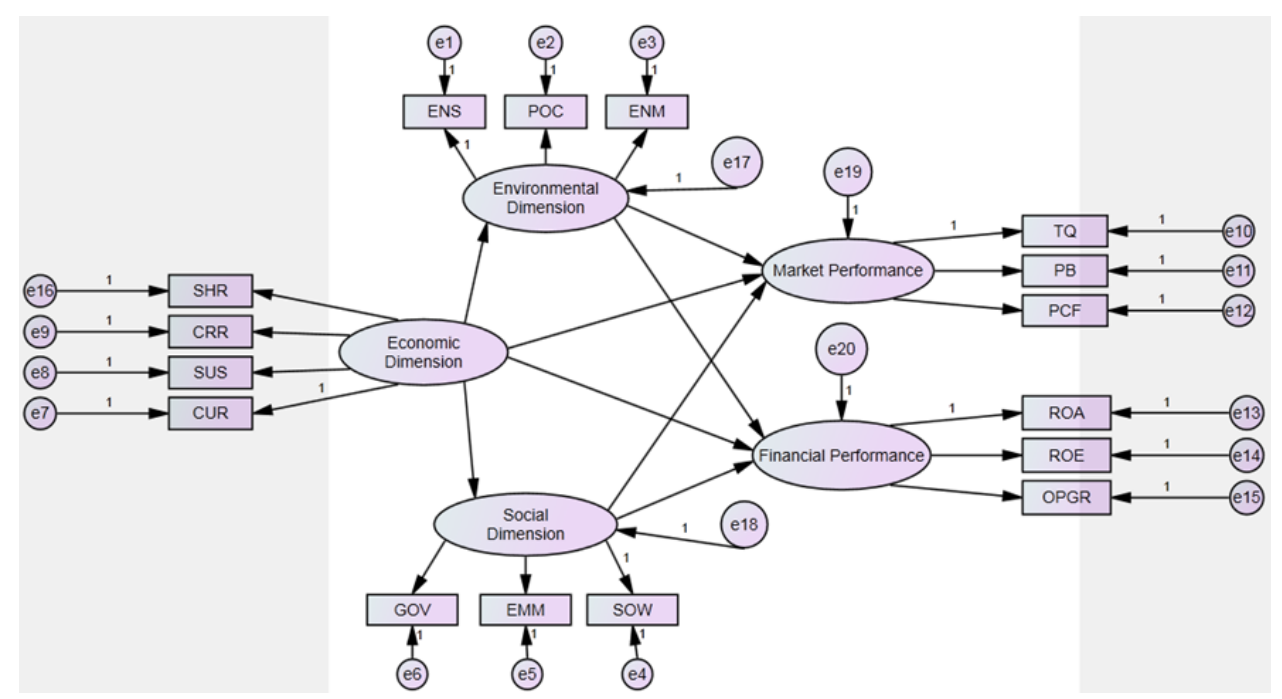

We used the AMOS statistical software to estimate the parameters of path relationship in the model. Table 9 shows the initial fitting results from the absolute fit indices. It can be observed that the GFI $(0.917)$ and RMSEA $(0.053)$ meet the requirement of model evaluation. However, AGFI (0.889) is less than the criterion (0.9). For relative fit indices, NFI (0.798), TLI (0.876), and CFI (0.897) are less than 0.9, which means that they do not meet the requirement of model evaluation. Hence, we modified the model using the modification indices (MI) and adding path relationships among related residuals. The new fitting results, presented in Table 10, shows a better model as all fit indices meet their respective requirements. The results are summarised in Figure 3. 
Table 9 Initial fitting results

\begin{tabular}{|c|c|c|c|}
\hline Path & Coefficient & C.R. & $p$-value \\
\hline Economic $\longrightarrow$ Environmental & 0.306 & 1.662 & 0.097 \\
\hline Economic $\longrightarrow$ Social & 0.807 & 1.808 & 0.071 \\
\hline Economic $\longrightarrow$ Market & 0.697 & 2.034 & 0.042 \\
\hline Economic $\longrightarrow$ Financial & 0.731 & 2.480 & 0.013 \\
\hline Environmental $\longrightarrow$ Market & -0.148 & -1.896 & 0.058 \\
\hline Environmental $\longrightarrow$ Financial & -0.309 & -4.054 & 0.000 \\
\hline Social $\longrightarrow$ Market & 0.224 & 2.096 & 0.036 \\
\hline Social $\longrightarrow$ Financial & 1.216 & 2.002 & 0.045 \\
\hline \multicolumn{4}{|c|}{ Fit indices } \\
\hline 0.917 & \multicolumn{2}{|c|}{ NFI } & 0.789 \\
\hline 0.889 & \multicolumn{2}{|c|}{ TLI } & 0.876 \\
\hline RMSEA & \multicolumn{2}{|c|}{ CFI } & 0.897 \\
\hline
\end{tabular}

Table 10 Final fitting results

\begin{tabular}{|c|c|c|c|}
\hline Path & Coefficient & C.R. & $P$ \\
\hline Economic $\longrightarrow$ Environmental & 0.222 & 1.741 & 0.083 \\
\hline Economic $\longrightarrow$ Social & 0.825 & 1.843 & 0.065 \\
\hline Economic $\longrightarrow$ Market & 0.863 & 2.075 & 0.038 \\
\hline Economic $\longrightarrow$ Financial & 0.902 & 3.121 & 0.002 \\
\hline Environmental $\longrightarrow$ Market & -0.174 & -1.965 & 0.049 \\
\hline Environmental $\longrightarrow$ Financial & -0.338 & -4.492 & 0.000 \\
\hline Social $\longrightarrow$ Market & 0.926 & 2.253 & 0.024 \\
\hline Social $\longrightarrow$ Financial & 0.808 & 2.025 & 0.043 \\
\hline \multicolumn{4}{|c|}{ Fit indices } \\
\hline 0.943 & & NFI & 0.864 \\
\hline AGFI & & TLI & 0.959 \\
\hline RMSEA & & CFI & 0.968 \\
\hline
\end{tabular}

Figure 3 CSRD and CS

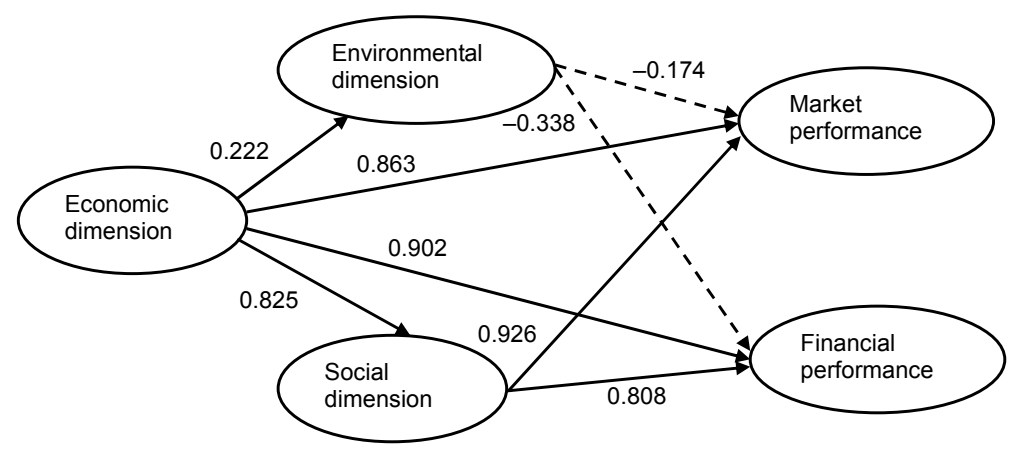




\subsection{Empirical results and analysis}

\subsubsection{Dimension relationship analysis}

The results in Table 10 show the effects of CSRD on CS. Stakeholders in the economic dimension have a strict legal relationship with companies and they have a direct influence on business operations. To obtain a stable material basis, companies need to take responsibility for them in the first place. Economic responsibility is the basis for taking other responsibilities. Other CSR activities extend from economic activities. If a company does not have a stable cash flow, it cannot have enough funds to support various CSR activities such as social welfare programmes and developing green technology. If a firm becomes bankrupt, this will not only bring loss to stakeholders in the economic dimension but also cause greater loss to stakeholders in the social dimension. For example, employees will be immediately faced with unemployment and loss of all benefits brought by CSR activities. Based on Tables 9 and 10, the standardised path coefficients of the effect of 'economic dimension on the environmental dimension' and 'economic dimension on social dimension' are 0.222 and 0.825 , respectively. The results are statistically significant, providing support for $\mathrm{H} 1 \mathrm{a}$ and $\mathrm{H} 1 \mathrm{~b}$. The results are consistent with the above argument that CSRD in the economic dimension has a positive influence on the environmental and social dimensions.

This result is similar to the study by Neumayer (2000), where it was observed that economic growth is good for most stakeholders in society and helps in achieving environmental protection. However, the effect of CSRD in the economic and social dimensions is greater than in the economic and environmental dimensions. This means that Chinese companies have more willingness to invest in social programmes than in environmental protection.

\subsubsection{Effect of the economic dimension}

This study defined shareholders, creditors, suppliers and customers as stakeholders in the economic dimension. They are important business partners who have a close relationship with corporate operations. They have a stake in the firm's survival and development, i.e., CS. Taking responsibility for them helps companies build a good image in business circles and attract more strategic investment partners. In this way, companies have a greater possibility of survival in the competitive global market. If a firm does not take responsibility for these stakeholders, it will bring greater costs to the firm and damage the CS, leading to loss of competitive edge. The results of SEM show that standardised path coefficients of 'economic dimension on market performance' and 'economic dimension on financial performance' are 0.863 and 0.902 , respectively. The results are statistically significant at the $5 \%$ level, thus providing support for $\mathrm{H} 1 \mathrm{c}$ and $\mathrm{H} 1 \mathrm{~d}$. The empirical results are consistent with the above argument that CSRD in the economic dimension has a positive effect on CS. This result is consistent with the research done by Bird et al. (2007), who also found that CSR management in the economic dimension can make contributions to CS.

\subsubsection{Effect of the environmental dimension}

The empirical results show that standardised path coefficients of 'environmental dimension on market performance' and 'environmental dimension on financial 
performance' are -0.174 and -0.338 , respectively. The results, although statistically significant, fail to support $\mathrm{H} 2 \mathrm{a}$ and $\mathrm{H} 2 \mathrm{~b}$. They imply that CSR information in the environmental dimension has a negative effect on CS. Two plausible explanation may be offered for this result. First, environmental disclosure has deferred effects. Kapur et al. (2011) argued that when a firm takes environmental responsibility, it needs to make huge investments in developing green technology and purchasing environmental protection equipment. Although this can reduce regulation costs and improve positive interaction between the corporation and society in the long-term, there is increased cost in the short-term because initial investments in environmental protection facilities are often expensive. Secondly, the payback period is relatively long, and the environmental benefits are often inconspicuous (Kapur et al., 2011). Based on the analysis above, the negative relationship between CSRD in the environmental dimension and CS may be a result of the imbalance between environmental protection inputs and outputs and the deferred effect of environmental benefits. The results are, however, in tandem with Hillman et al. (2001), who argued that environmental management has a negative effect on a firm's value.

\subsubsection{Effect of the social dimension}

This study investigates government, employee, and social welfare as the primary targets of CSRD in the social dimension. CSR management of these stakeholders can help firms to relieve pressure from government regulation and social supervision so as to obtain greater flexibility of business operation, and even tax preference or some policy support. In addition, good performance in taking social responsibility contributes to attracting talent and reducing costs. Firms that have good social reputations have the potential to recruit outstanding potential employees and reduce employee turnover (Schreck, 2011). Good workers with high working efficiency help improve the CS.

The empirical results are consistent with the above analysis. From Table 10, it can be seen that standardised path coefficients of 'Social dimension on market performance' and 'social dimension on financial performance' are 0.926 and 0.808 , respectively. The results are statistically significant at the $5 \%$ level, thus providing support for $\mathrm{H} 3 \mathrm{a}$ and $\mathrm{H} 3 \mathrm{~b}$. CSRD in the social dimension has positive effect on CS. This result is consistent with Heal (2005), who analysed CSR from economic and financial perspectives and found that social programmes can contribute to financial and market performance. Consistent with Yekini and Jallow (2012), CSR information in the social dimension can be viewed as an effective marketing strategy and signal of corporate citizenship. It provides social stakeholders with needed information and reconciles the goals of society and corporations (Yekini et al., 2017). The relationship between corporation and society is improved. A good corporate image makes the brand and product stand out from the competition, which leads to the enhancement of CS (Mandhachitara and Poolthong, 2011).

\section{Conclusions}

This study set out to examine the effect of CSRD on CS in China. By drawing insights from the TBL and stakeholder theory, a CSRD index was constructed. The research results reveal that most Chinese companies stayed at the intermediate level of CSRD. 
Only $10 \%$ of the sampled companies had outstanding performance on CSRD. In addition, CSRD has different focuses in various stakeholder dimensions. The sampled companies have good performance on CSRD targeting shareholders, government, and employees, but the information disclosure about the environment and social welfare was worse. The findings also show that CSRD in the economic and social dimensions have positive effects on CS. However, this research found that there is a negative relationship between CS and CSRD in the environmental dimension. This result does not support the proposed hypotheses. It may result from the imbalance between environmental protection inputs and outputs or the deferred effect of environmental benefits. Furthermore, this study found relationships among the different dimensions of CSRD. The economic dimension has a positive effect on the environmental and social dimensions. Taking responsibility for stakeholders in the economic dimension helps firms to obtain a stable material basis which supports other CSR activities, particularly for marginal stakeholders.

This study reveals the current situation of CSRD in China. There is room for Chinese companies to improve the quality of CSRD, particularly in the environmental dimension. Given the poor environmental disclosure, one can insinuate that environmental protection and its associated activities are generally poor amongst Chinese companies. We, therefore recommend that the government setup institutions with the primary responsibility of regulating the activities of companies in China as they relate to the environment. There should be statutory environmental disclosure in the annual reports by firms of whether they have complied with regulations, and if not, of the reasons why not. There is a need to create general awareness of the need for environmental protection amongst Chinese companies. Furthermore, there should be incentives and punishments for environmental responsibility and irresponsibility respectively. Overall, the empirical results show that CSRD has a positive effect on CS.

Our study has contributed to the CSR/sustainability literature by providing evidence from the Chinese market on the effect of CSR activities on the CS of Chinese companies and the introduction of a comprehensive CSR information disclosure index capable of guiding researchers, managers and policy makers in measuring and designing criteria for CSR activities and reporting. Our findings have also opened up a debate for future research into why CSRDs in the environmental dimensions produced a negative relationship with CS. It will also be interesting to replicate this study in other emerging markets, such as the Japanese capital market.

\section{References}

Adams, C.A., Hill, W. and Roberts, C. (1998) 'Corporate social reporting practices in Western Europe: legitimating corporate behaviour', The British Accounting Review, Vol. 30, No. 1, pp.1-21.

Aggarwal, P. (2013) 'Relationship between environmental responsibility and financial performance of firm: a literature review', IOSR Journal of Business and Management, Vol. 13, No. 1, pp.13-22.

Ahmed, K. and Courtis, J. (1999) 'Associations between corporate characteristics and disclosure levels in annual reports: a meta-analysis', The British Accounting Review, Vol. 31, No. 1, pp.35-61.

Babiak, K. and Trendafilova, S. (2011) 'CSR and environmental responsibility: motives and pressures to adopt green management practices', Corporate Social Responsibility and Environmental Management, Vol. 18, No. 1, pp.11-24. 
Baron, D.P. (2010) Social Pressure Affect Corporate Strategy and Performance, Stanford Business [online] http://csi.gsb.stanford.edu/social-pressures-affect-corporate-strategy-andperformance-0 (accessed 25 June 2015).

Beurden, P. and Gössling, T. (2008) 'The worth of values - a literature review on the relation between corporate social and financial performance', Journal of Business Ethics, Vol. 82, No. 2, pp.407-424.

Bhattacharyya, S.S. (2010) 'Exploring the concept of strategic corporate social responsibility for an integrate perspective', European Business Review, Vol. 22, No. 1, pp.82-101.

Bird, R., Hall, A.D., Momentè, F. and Reggiani, F. (2007) 'What corporate social responsibility activities are valued by the market?', Journal of Business Ethics, Vol. 76, No. 2, pp.189-206.

Bollen, K.A. (1989) Structural Equations with Latent Variables, John Wiley \& Sons, Inc, New York.

Brammer, S. and Millington, A. (2005) 'Corporate reputation and philanthropy: an empirical analysis', Journal of Business Ethics, Vol. 61, No. 1, pp.29-44.

Chi, C.G. and Gursoy, D. (2009) 'Employee satisfaction, customer satisfaction, and financial performance: an empirical examination', International Journal of Hospitality Management, Vol. 28, No. 2, pp.245-253.

Clarkson, M.E. (1995) 'A stakeholder framework for analysing and evaluating corporate social performance', Academy of Management Review, Vol. 20, No. 1, pp.92-117.

Cooke, F.L. (2005) HRM, Work and Employment in China, Psychology Press, New York, USA.

Cormier, D. and Magnan, M. (2007) 'The revisited contribution of environmental reporting to investors' valuation of a firm's earnings: an international perspective', Ecological Economics, Vol. 62, No. 3, pp.613-626.

De-zhong, D., Leng, G. and Huang, P. (2006) 'Analysis of environmental samples', Chinese Journal of Analysis Laboratory, Vol. 6, No. 6, p.28.

Elkington, J. (1998) Cannibals with Forks: The Triple Bottom Line of 21st Century Business, Conscientious Commerce, New Society Publishers, USA.

Freedman, M. and Patten, D.M. (2004) 'Evidence on the pernicious effect of financial report environmental disclosure', Accounting Forum, Vol. 28, No. 1, pp.27-41.

Freeman, R.E. (1984). Strategic Management: A Stakeholder Approach, Pitman, Boston.

Frost, G.R. and Wilmshurst, T.D. (2000) 'The adoption of environment-related management accounting: an analysis of corporate environmental sensitivity', Accounting Forum, Vol. 24, No. 4, pp.344-365.

Gautam, R., Singh, A. and Bhowmick, D. (2017) 'Demystifying relationship between corporate social responsibility (CSR) and financial performance: an Indian business perspective', Independent Journal of Management \& Production, Vol. 7, No. 2, pp.1034-1062.

Gjølberg, M. (2009) 'Measuring the immeasurable? Constructing an index of CSR practices and CSR performance in 20 countries', Scandinavian Journal of Management, Vol. 25, No. 1, pp.10-22.

Gras-Gil, E., Manzano, M. and Fernández, J. (2016) 'Investigating the relationship between corporate social responsibility and earnings management: evidence from Spain', Business Research Quarterly, Vol. 19, No. 4, pp.289-299.

Griffin, P.A. and Sun, Y. (2013) 'Going green: market reaction to CSR wire news releases', Journal of Accounting and Public Policy, Vol. 32, No. 2, pp.93-113.

Haniffa, R.M. and Cooke, T.E. (2002) 'Culture, corporate governance and disclosure in Malaysian corporations', Abacus, Vol. 38, No. 3, pp.317-349.

Heal, G. (2005) 'Corporate social responsibility: an economic and financial framework', The Geneva Papers on Risk and Insurance - Issues and Practice, Vol. 30, No. 3, pp.387-409.

Hillman, A.J., Keim, G.D. and Luce, R.A. (2001) 'Board composition and stakeholder performance: do stakeholder directors make a difference?', Business \& Society, Vol. 40, No. 3, pp.295-314. 
Holmes, F. (2010) How Government Policies Affect Market, Financial sense [online] http://www.financialsense.com/contributors/frank-holmes/how-government-policies-affectmarkets (accessed 25 June 2015).

Jackson, A., Boswell, K. and Davis, D. (2011) 'Sustainability and triple bottom line reporting what is it all about', International Journal of Business, Humanities and Technology, Vol. 1, No. 3, pp.55-59.

Jamil, C.Z.M., Alwi, K. and Mohamed, R. (2003) 'Corporate social responsibility disclosure in the annual reports of Malaysian companies: a longitudinal study', Analysis, Vol. 10, No. 1, pp.139-159.

Jawahar, I.M. and McLaughlin, G.L. (2001) 'Toward a descriptive stakeholder theory: an organisational life cycle approach', Academy of Management Review, Vol. 26, No. 3, pp.397-414.

Johnson, G., Whittington, R. and Scholes, K. (2008) Exploring Corporate Strategy: Text and Cases, Multimedia 8th edition, Harlow, Prentice Hall FT.

Kanbur, R. and Zhang, X. (2005) 'Fifty years of regional inequality in China: a journey through central planning, reform, and openness', Review of Development Economics, Vol. 9, No. 1, pp.87-106.

Kapur, N., Hiller, J., Langdon, R. and Abramson, A. (2011) Show Me the Money: Energy Efficiency Financing Barriers and Opportunities.

King, A., Lenox, M. and Barnett, M. (2002) 'Strategic responses to the reputations commons problem', in Hoffman, A.J. and Ventresca, M.J. (Eds.): Organisations, Policy, and The Natural Environment: Institutional and Strategic Perspectives, pp.393-406, Stanford University Press, Stanford, CA.

Kline, R.B. (1998) Principles and Practice of Structural Equation Modelling, The Guilford Press, New York.

KPMG (2013) The KPMG Survey of Corporate Responsibility Reporting 2013, KPMG International.

Laiho, T. (2011) Agency Theory and Ownership Structure - Estimating the Effect of Ownership Structure on Firm Performance [online] https://aaltodoc.aalto.fi/handle/123456789/629 (accessed 25 June 2015).

Li, S., Ragu-Nathan, B., Ragu-Nathan, T.S. and Rao, S.S. (2006) 'The impact of supply chain management practices on competitive advantage and organisational performance', Omega, Vol. 34, No. 2, pp.107-124.

Liu, X. and Anbumozhi, V. (2009) 'Determinant factors of corporate environmental information disclosure: an empirical study of Chinese listed companies', Journal of Cleaner Production, Vol. 17, No. 6, pp.593-600.

Loew, T., Ankele, K., Braun, S. and Clausen, J. (2004) 'Significance of the CSR debate for sustainability and the requirements for companies', Future E.V. and Institute for Ecological Economy Research, pp.8-9.

Mandhachitara, R. and Poolthong, Y. (2011) 'A model of customer loyalty and corporate social responsibility', Journal of Services Marketing, Vol. 25, No. 2, pp.122-133.

Margolis, J.D. and Walsh, J.P. (2003) 'Misery loves companies: rethinking social initiatives by business', Administrative Science Quarterly, Vol. 48, No. 2, pp.268-305.

Meng, X.H., Zeng, S.X., Tam, C.M. and Xu, X.D. (2013) 'Whether top executives' turnover influences environmental responsibility: from the perspective of environmental information disclosure', Journal of Business Ethics, Vol. 114, No. 2, pp.341-353.

Menz, K.M. (2010) 'Corporate social responsibility: is it rewarded by the corporate bond market? A critical note', Journal of Business Ethics, Vol. 96, No. 1, pp.117-134.

Mitchell, R.K., Agle, B.R. and Wood, D.J. (1997) 'Toward a theory of stakeholder identification and salience: defining the principle of who and what really counts', Academy of Management Review, Vol. 22, No. 4, pp.853-886. 
Mullich, J. (2011) 'Corporate social responsibility emerges in China', The Wall Street Journal [online] http://online.wsj.com/ad/article/chinaenergy-responsibility (accessed 25 June 2015).

Murphy, C.J. (2002) The Profitable Correlation between Environmental and Financial Performance: A Review of the Research, Light Green Advisors, Inc.

Nakao, Y., Amano, A., Matsumura, K., Genba, K. and Nakano, M. (2007a) 'Relationship between environmental performance and financial performance: an empirical analysis of Japanese corporations', Business Strategy and the Environment, Vol. 16, No. 2, pp.106-118.

Nakao, Y., Nakano, M., Amano, A., Kokubu, K., Matsumura, K. and Gemba, K. (2007b) 'Corporate environmental and financial performances and the effects of information-based instruments of environmental policy in Japan', International Journal of Environment and Sustainable Development, Vol. 6, No. 1, pp.95-112.

Neumayer, E. (2000) 'Beyond growth: against the misplaced focus on economic growth', Politische öKologie, Vol. 66, pp.19-23.

Norman, W. and MacDonald, C. (2004) 'Getting to the bottom of triple bottom line', Business Ethics Quarterly, Vol. 14, No. 2, pp.243-262.

Peppard, J. (2000) 'Customer relationship management (CRM) in financial services', European Management Journal, Vol. 18, No. 3, pp.312-327.

Pivato, S., Misani, N. and Tencati, A. (2008) 'The impact of corporate social responsibility on consumer trust: the case of organic food', Business Ethics: A European Review, Vol. 17, No. 1, pp.3-12.

Qiang, Q. (2003) 'Corporate governance and state-owned shares in China listed companies', Journal of Asian Economics, Vol. 14, No. 5, pp.771-783.

Richardson, A.J. and Welker, M. (2001) 'Social disclosure, financial disclosure and the cost of equity capital', Accounting, Organisations and Society, Vol. 26, Nos. 7-8, pp.597-616.

RobecoSAM (2015) Dow Jones Sustainability Indices Methodology, S\&P Dow Jones Indices, McGraw Hill Financial.

Ruf, B.M., Muralidhar, K., Brown, R.M., Janney, J.J. and Paul, K. (2001) 'An empirical investigation of the relationship between change in corporate social performance and financial performance: a stakeholder theory perspective', Journal of Business Ethics, Vol. 32, No. 2, pp.143-156.

Savitz, A. (2013) The Triple Bottom Line: How Today's Best-Run Companies are Achieving Economic, Social and Environmental Success--And How You Can Too, John Wiley \& Sons, San Francisco, USA.

Sawayda, J. (2013) The Debate over the Shareholders Model of Corporate Governance, Daniels Fund Ethics Initiative, University of New Mexico [online] http://danielsethics.mgt.unm.edu/ pdf/shareholder-model-di.pdf (accessed 8 June 2017).

Schneider, B., Hanges, P.J., Smith, D.B. and Salvaggio, A.N. (2003) 'Which comes first: employee attitudes or organizational financial and market performance?', Journal of Applied Psychology, Vol. 88, No. 5, p.836.

Schreck, P. (2011) 'Reviewing the business case for corporate social responsibility: new evidence and analysis', Journal of Business Ethics, Vol. 103, No. 2, pp.167-188.

Slaper, T.F. and Hall, T.J. (2011) 'The triple bottom line: what is it and how does it work', Indiana Business Review, Vol. 86, No. 1, pp.4-8.

Stanny, E. and Ely, K. (2008) 'Corporate environmental disclosures about the effects of climate change', Corporate Social Responsibility and Environmental Management, Vol. 15, No. 6, pp.338-348.

Tsoutsoura, M. (2004) Corporate Social Responsibility and Financial Performance, Working Paper Series, University of California, USA, Permalink [online] https://escholarship.org/ uc/item/111799p2 (accessed 25 June 2015).

Turker, D. (2009) 'Measuring corporate social responsibility: a scale development study', Journal of Business Ethics, Vol. 85, No. 4, pp.411-427. 
Uadiale, O.M. and Fagbemi, T.O. (2012) 'Corporate social responsibility and financial performance in developing economies: the Nigerian experience', Journal of Economics and Sustainable Development, Vol. 3, No. 4, pp.44-54.

Van Marrewijk, M. (2003) 'Concepts and definitions of CSR and corporate sustainability: between agency and communion', Journal of Business Ethics, Vol. 44, Nos. 2-3, pp.95-105.

Verbeeten, F., Gamerschlag, R. and Möller, K. (2016) 'Are CSR disclosures relevant for investors? Empirical evidence from Germany', Management Decision, Vol. 54, No. 6, pp.1359-1382.

Wagner, S.M. and Johnson, J.L. (2004) 'Configuring and managing strategic supplier portfolios', Industrial Marketing Management, Vol. 33, No. 8, pp.717-730.

Wind Info (2015) About Us, Wind Information Co., Ltd. [online] http://www.wind.com.cn/ en/aboutus.html (accessed 9 June 2015).

Yao, S., Wang, J. and Song, L. (2011) Determinants of Social Responsibility Disclosure by Chinese Firms, China Policy Institute, The University of Nottingham.

Yekini, K. (2012) Corporate Community Involvement Disclosure: An Evaluation of the Motivation \& Reality, Unpublished PhD thesis, De Montfort University, Leicester, UK.

Yekini, K. and Jallow, K. (2012) 'Corporate community involvement disclosures in annual report: a measure of corporate community development or a signal of CSR observance?', Sustainability Accounting, Management and Policy Journal, Vol. 3, No. 1, pp.7-32.

Yekini, K., Adelopo, I. and Adegbite, E. (2017) 'The impact of community expectations on corporate community involvement disclosures in the UK', Accounting Forum, Vol. 41, No. 3 , pp.234-252.

Yekini, K., Adelopo, I., Androkopolous, P. and Yekini, S. (2015) 'Impact of board independence on the quality of community disclosures in annual reports', Accounting Forum, Vol. 39, No. 4, pp.249-267.

Yekini, K., Adelopo, I., Wang, Y. and Song, S. (2018) 'Post-regulation effect on factors driving environmental disclosures among Chinese listed firms', Accounting Research Journal, in press, DOI: 10.1108/ARJ-01-2017-0018.

Zhang, X. and Gu, P. (2012) On the Relationship Between CSR and Financial Performance: An Empirical Study of US Firms, Jönköping University [online] http://www.diva-portal.org/ smash/get/diva2:530678/FULLTEXT01.pdf (accessed 14 June 2017). 